\title{
Introductory Biology Courses: A Framework To Support Active Learning in Large Enrollment Introductory Science Courses
}

\author{
Ann C. Smith, ${ }^{*}$ Richard Stewart, ${ }^{*}$ Patricia Shields, ${ }^{*}$ Jennifer Hayes-Klosteridis, ${ }^{\dagger}$ \\ Paulette Robinson, ${ }^{\ddagger}$ and Robert Yuan*
}

*Department of Cell Biology and Molecular Genetics, ${ }^{\dagger}$ College of Life Sciences, ${ }^{\ddagger}$ Office of Information Technology, University of Maryland, College Park, MD 20742

Submitted August 29, 2004; Accepted December 23, 2004

Monitoring Editor: James Gentile

\begin{abstract}
Active learning and research-oriented activities have been increasingly used in smaller, specialized science courses. Application of this type of scientific teaching to large enrollment introductory courses has been, however, a major challenge. The general microbiology lecture/ laboratory course described has been designed to incorporate published active-learning methods. Three major case studies are used as platforms for active learning. Themes from case studies are integrated into lectures and laboratory experiments, and in class and online discussions and assignments. Students are stimulated to apply facts to problem-solving and to learn research skills such as data analysis, writing, and working in teams. This course is feasible only because of its organizational framework that makes use of teaching teams (made up of faculty, graduate assistants, and undergraduate assistants) and Web-based technology. Technology is a mode of communication, but also a system of course management. The relevance of this model to other biology courses led to assessment and evaluation, including an analysis of student responses to the new course, class performance, a university course evaluation, and retention of course learning. The results are indicative of an increase in student engagement in research-oriented activities and an appreciation of real-world context by students.
\end{abstract}

Keywords: active learning, case studies, introductory biology, undergraduate students, technology

\section{INTRODUCTION}

Many reports in the science education literature have shown that our traditional lecture offerings and accompanying "cookbook" labs are missing the educational mark. The concern reverberating in the science education community is that we need to transform our classes from instructor-led courses to dynamic student-centered learning arenas that engage our students in research-oriented learning (Wood, 2003; National Research Council [NRC], 2003). This has led to a call to arms in research universities. Despite the farreaching concern and the availability of proven methods for incorporating active learning into our courses (Handelsman et al., 2004), many of us teaching large lecture introductory

DOI: 10.1187/cbe.04-08-0048

Address correspondence to: Ann C. Smith (asmith@umd.edu). classes have been leery of making a transition. At first consideration it seems straightforward to add a few new teaching strategies to a course. But when faced with 200 students and more in a lecture hall, even distributing a handout requires layers of organization (must plan for the time in the class period for distribution, for the method of distribution to ensure that all students receive the handout and to ensure that students do not take extra copies, and for the method to reach absent students). Upon reflection, even enthusiastic and energetic teachers quickly realize that converting a large-enrollment, lecture-based class to a course with an active-learning foundation will require time and organization. For faculty at a research university with already significant demands besides teaching, the choice to develop a framework to support active learning can be a strong deterrent to the request for change. In this article we report how we have responded to the call-defining a 
framework to allow active learning to be incorporated into a large lecture introductory science course in a meaningful and manageable manner.

At large research universities, most introductory science courses share a similar format: a large student enrollment, generally two to three lectures per week taught in a large lecture hall, and distinct lab sections taught in a separate space. Often, extremely large courses (600-1,000 students enrolled per year) will have multiple lecture sections. The large student enrollment, multiple instructors, and the limitations of the traditional course lecture/lab structure thus complicate changes in course design. Our course, BSCI 223 General Microbiology, is a one-semester introductory microbiology course serving 750 students per year. It is set up with two 50-min lectures and two 2-hr lab periods each week. Our goal was to incorporate active-learning strategies into this class in a manner that could be reproducible for other introductory biology courses, would not require increased funding, and could be accomplished with the staffing presently available for the course.
Our course redesign followed a detailed examination of its various components: the role of the instructors, the use of the lecture and lab periods, and the role of the textbook. We reviewed the published methods of active learning and many approaches to teaching large classes that appear at Web sites of many large research universities. We wanted to create a rich, multifaceted course that integrated active learning into every facet of the course. We wanted the activities to have meaning such that students would be engaged in activities similar to those of a practicing scientist. Such an effort, as proposed by Johnson and Malinowski (2001), required a complete shift in course philosophy.

Case studies and associated problems are effective in engaging the learner (Herreid, 1998). We chose case studies to serve as our core active-learning tool. In addition, we have included aspects of Just in Time Teaching (JITT; Marrs and Novak, 2004), Peer-Led Team Learning (PLTL; PLTL Workshop Project, 2004), techniques such as Think-Pair-Share (TP-S; Allen and Tanner, 2002), Inquiry labs (Handelsman et al., 2004), and problem-based learning (PBL; Allen, 1996).

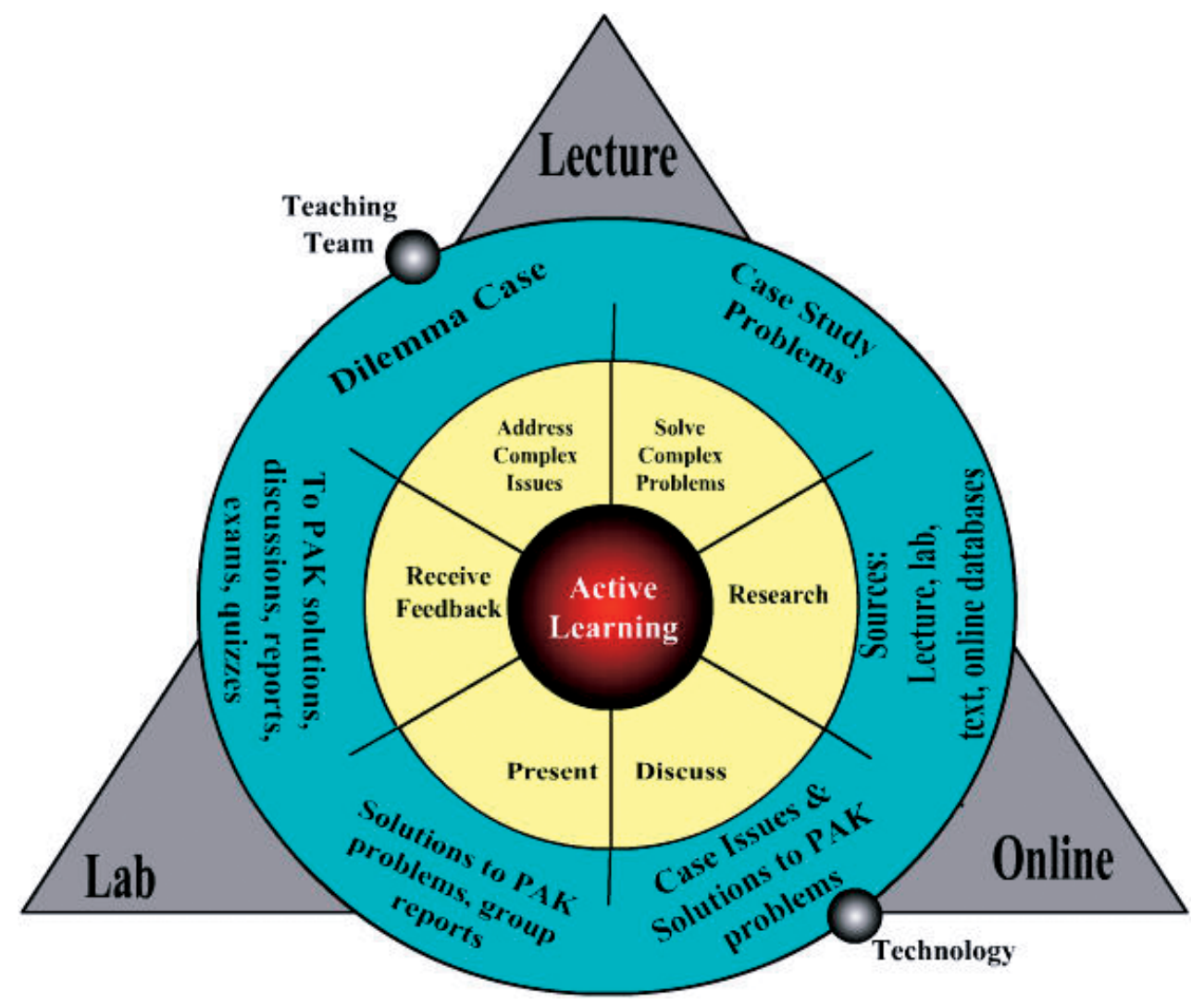

Figure 1. The Active Learning Course Framework (ALCF). Three learning environments - the lecture, the lab, and the online learning environment-provide the time and space to support the ALCF. The three environments are linked through the actions of the teaching team and the use of technology depicted in the diagram as small circles. The active-learning mission of the ALCF is represented as the center circle of the ALCF diagram. Within the ALCF, active learning is designed to engage students in activities valuable to a research scientist; these activities are in the first ring, growing from the central circle. To place the activities within a context, to provide meaning to the students, and to serve as a pedagogical link, the ALCF employs case studies and associated problems (which we refer to as PAK problems, for participation/applied knowledge problems). The animated version of Figure 1 shows how the course environments come together to support the active-learning mission of the ALCF, the connecting role of the teaching team and technology, as well as the role of various active-learning strategies: Just in Time Teaching (JITT; Marrs and Novak, 2004), Peer-Led Team Learning (PLTL; PLTL Workshop Project, 2004), techniques such as Think-PairShare (T-P-S; Allen and Tanner, 2002), Inquiry labs (Handelsman et al., 2004), and problem-based learning (PBL; Allen, 1996). 
Over the past eight years, we have tested various combinations of active-learning strategies. To guide our path, we have relied on student satisfaction surveys, student focus groups, and feedback from our teaching assistants, as well as on our personal observations. This work began from an interest in better serving our students and has grown into a major science education project. The result of our work is a new course framework: the Active Learning Course Framework (ALCF). The ALCF has been in place in our course for two years, and we have begun implementing aspects of the framework in other introductory biology courses. Figure 1 shows the design of the ALCF. The animated version of the figure illustrates the layers of our course design. The original course had the traditional course structure with two distinct learning environments: lecture and lab. We added the online area to provide another nexus in space and time for learning and to serve as the communication and distribution center for the course. In large lecture courses, a major barrier to change is the difficulty associated with disseminating information, collecting student work, providing feedback to students, and supporting and monitoring teamwork. The use of technology provided a solution and allowed us to link lecture and lab, as well as online learning opportunities, in a cohesive manner. Students enter the online environment to find lab-oriented material (lab syllabus and lab manual) and lecture-oriented material (lecture syllabus and course PowerPoint presentations). Technology serves as a first formal link between course environments. A second formal link is through the action of the instructors. We formed a team with the course lecturers, the lab instructor, and the teaching assistants. Each team member was aware of and supported the actions and roles of the others. The connections established form the structure of the course. These two formal links allowed us to add case studies. Case studies tie the course material together thematically. In Figure 1 the central circle represents our course emphasis: active learning. The first ring shows the goals of the research scientist, the second ring shows how we use case studies and associated problems (which we call participation/applied knowledge [PAK] problems - see Table 2) and other forms of engagement including aspects of the proven methods of JITT (Marrs and Novak, 2004), PLTL (PLTL Workshop Project, 2004), T-PS (Allen and Tanner, 2002), PBL (Allen, 1996), and Inquiry labs (Handelsman et al., 2004).

To support case-based learning, we divide our onesemester course into three modules (Table 1). Each module is anchored by a case study; all lab, lecture, and activelearning experiences are connected to the case-study story. For example, consider the first module. The content covered in Module 1, "Bacterial structure/function, Bacterial metabolism and growth" is brought to light in a case study about a fictional space mission where the outer lycra covering of a space sample collector is degraded upon return from a fictional planet. Students investigate the possibility that microbes associated with the probe may be the cause of the degradation. Students must use information presented in lecture, in lab, and from their own research and reading of the text to answer case-study questions and to complete a group laboratory assignment. Linking material helps students build knowledge and improves retention (Lux, 2002). The ALCF serves to support connections between all aspects of the course: the people, the learning environments, and the pedagogy. Each course component that was mod- ified in the redesign of the course is discussed in detail below.

\section{COURSE DESIGN}

\section{Human Resources: The Teaching Team}

Incorporating active learning into a course design is labor intensive. To address this challenge, we employed a teaching team comprising biology faculty, graduate teaching assistants (GTAs), undergraduate teaching assistants (UTAs), and education and information technology consultants. Because we are part of a large research university where we have multiple sections for the same course and graduate students serve as teaching assistants, we were able to use existing course staffing to our advantage. For each lecture section we have assigned one course instructor, and for the lab there is an additional faculty instructor. For the three sections of our course taught in the year, we have a team of four faculty members. In addition, there is one GTA for each set of two lab sections. Our goal was to transform our course using available staffing. However, we found that some course tasks required more instructor effort. To support our activelearning mission, we added one UTA per lab section. Our teaching team is structured to allow each member to have a primary responsibility, as well as to share in the activelearning activities. At a small college, faculty may seek to collaborate with instructors teaching the same course (Introductory Biology, for example) at another similar institution.

In the teaching team, each faculty member provided a unique perspective. Although our team has varied somewhat over the last eight years as faculty members have rotated through the course, the group has always benefited from the diversity of perspectives that a team composed of full professors, associate and assistant professors, and instructors would provide. In the development phase of this project, the responsibility of the team was to prepare active-learning components for the course. The development benefited from the variety of expertise and experience of the faculty. Within the implementation phase of the ALCF, teamwork and diversity continues to be beneficial. Each faculty member finds a niche in the course when being part of the team. Research faculty members have been particularly interested in infusing case studies, case-study problems, and course assignments with data and data analysis. The instructors on our team have focused on technology and pedagogy. Even though the framework for the course has been established, assignments and case-study problems are altered each semester. This keeps the course fresh and current and restricts student sharing of information with graduates of the course. Working as a team provides a mechanism that ensures that all aspects of the course (for example, lab and lecture) will be linked and that the work involved in implementing active learning is shared.

On our team, faculty members are divided with respect to major responsibility: lecturer versus coordinator of laboratory and online environments. Within their major responsibility area, faculty members have the opportunity to add their own flavor to the course. Yet the faculty works together to run the course: defining learning goals, discussing and implementing active-learning strategies in the lab and in the lecture, setting the course syllabus, updating case studies and assignments, using and developing uses for technology 
Table 1. ALCF for BSCI 223

Learning goal topics $\quad$ Case study $\quad$ Lecture

(American Society for Micro- The case and PAK problems (Table 2) are distributed biology Undergraduate Education Curriculum Guidelines, 1994)

Module 1:

Prokaryotic structure/ function

Bacterial metabolism

Bacterial growth

Control of growth

Comparison to eukaryotes online in a time-released manner. Each PAK set has three problems.

Case 1: Fictional story about a collection robot (ELVIS) returning from a mission to a fictional planet. Upon return to earth, it is noted that a microbe has destroyed polyurethane components.

PAK 1.1

Microbial structure and microscopy

PAK 1.2

Microbial structures and functions

PAK 1.3

Bacterial metabolism

PAK 1.4

Control of bacterial growth

(PAK 1.4 is an extra problem set that is discussed face to face in lab, rather than online. Students discuss the possibility of contamination of the ELVIS probe)

Example of how coverage of one concept is linked

PAK 1.1 Question A:

"Using light microscopy, you examine the soil samples and the 'goo' from the degraded polyurethane. Will this approach allow you to observe all microorganisms present in the samples? Why or why not? What are the limitations of this approach?"
Module 2:

Bacterial genetics

Information flow

DNA replication

Transcription

Translation

Horizontal and vertical gene transfer

Viruses as genetic elements Genetic engineering Biotechnology

Case 2: Fictional story "A Farmer's Dilemma." Two organic farmers struggle with corn borer infestation

Dilemma: Should the farmers plant a pest-resistant transgenic crop?

PAK 1.1

Information flow, comparison of eukaryotes and prokaryotes

PAK 1.2

Mutation, implications on information flow, requires National Center for Biotechnology Information sequence search

PAK 1.3

Genetic engineering, biotechnology, Agrobacterium system, transgenic plants

Module 3:

Microbial ecology

The animal host

Pathogenicity

Virulence

The host response

Immunology

Epidemiology

Prevention and treatment

Bacterial and

viral infectious disease
Case 3: Fictional story of a student who contracts a streptococcal infection that becomes systemic. In discussion, a connection to Jim Henson (University of Maryland alumnus who died of a streptococcal infection) is highlighted.

PAK 1.1

Normal flora, innate immune response

PAK 1.2

Pathogenicity, virulence factors, B cell response

PAK 1.3

Immune memory, treatment, antibiotic resistance
$75 \%$ of lecture time is spent in formal lecture presentation of module content

$25 \%$ is spent in discussion of case-study

(PAK) questions.

Lecture set 1

Lecture 1: Importance of microbiology/history

Lecture 2: Definition of a prokaryote

Lecture 3: Microbial structure and function

Lecture 4: Microbial structure and function

Lecture 5: Microbial nutrition and growth

Lecture 6: Microbial metabolism

Lecture 7: Microbial metabolism

Lecture 8: Control of microbial growth
Lecture content covers the basic characteristics that define a bacterium: the size, the shapes, and the structures observable by light microscopy. Prokaryotes are contrasted with eukaryotes.

\section{Lecture set 2 :}

Lecture 1: Information storage, prokaryotes and eukaryotes

Lecture 2: Information flow

Lecture 3: Change in genotype, gene flow, and mutation.

Lecture 4: Regulation of gene expression

Lecture 5: Genetic engineering, biotechnology

Lecture 6: Viruses

Lecture 7: Bacteriophage

Lecture 8: Animal viruses

BSCI 223 is divided into three basic theme areas: Module 1 covers theme area 1, prokaryotic structure/function; Module 2 covers theme area 2 , bacterial genetics and biotechnology; and Module 3 covers theme area 3, host/pathogen relations and applied microbiology. Each module is anchored by a case study and three sets of PAK problems. Each case was chosen to engage students in the learning goals for the module. (We wrote the case studies referenced and their publication is in preparation.) Each PAK set has three challenging problems. Lecture content and lab experiences are resources for students to answer PAK questions and problems posed in lab exercises and in course assignments. One specific example within Module 1 is highlighted to show the detail of the linkages between lecture, lab, assignments, PAK problems, and the case study. (See information relating to PAK 1.1.) Students are actively engaged in learning goals at all times through content-linked experiences in the three course environments: lecture, lab, and online. 
Table 1. (Extended)

In each lab students learn standard protocols and are required to apply the protocols to specific problems. Some labs are linked to long-term projects and larger assignments.

Lab set 1 :

Lab 1: Diversity and microscopy

Lab 2: Staining and streaking

Lab 3: Morphological characteristics

Lab 4: Cultivation of bacteria

Lab 5: Bacterial metabolism: fermentation and respiration

Lab 6: Antimicrobial agents and antibiotics

Lab 7: Bacterial growth

Lab 8: Sterilization techniques

Students learn the basic protocols:

Microscopy: operation of bright field,

phase contrast, and dark field scopes Sample preparation: Wet mount, simple stain, complex stains (gram stain, endospore stain, and capsule stain)

Lab protocols are linked to and extend knowledge of Case 2 topics.

Lab 9: Phenotype and genotype (use of Lac Operon system)

Lab 10: Enzyme induction (Lac Operon)

Lab 11: Agrobacterium transformation of Arbidopsis

Lab 12: Titration of bacteriophage
Assignment 1 is a group project that requires students to analyze mock ELVIS samples using protocols learned in lab and address a case-related hypothesis. The project culminates in a group-authored report presented as a Web page poster.

Hypothesis: Samples from the ELVIS probe are contaminated with bacteria from earth.
Students apply standard protocols to begin the analysis of the "samples" from the ELVIS probe.
Assignment 2 is a discussion of three major issues relevant to Case 2. See Table 3. Students must research issues, discuss in small groups online, and then regroup to write a position paper relevant to the Case 2 dilemma: Should the organic farmers plant Bacillus thuringiensis corn? The students act in the role as scientific consultants.
Lab 13: Diagnostics: Gram-positive cocci (two lab periods)

Lab 14: Diagnostics: Foodborne illness (four lab periods)

Lab 15: Biotechnology and food: yogurt making
Lab 14 is an extended critical-thinking lab on the topics of infectious disease and its diagnosis. This lab is complementary to Case 3 highlighting an additional portal of entry. Case 3 deals with skin breaks; Lab 14 highlights foodborne infections. The lab challenge relates to a disease outbreak. Students act as teams of microbiologists to determine and to demonstrate. in the course, as well as mentoring GTAs and UTAs. In addition, on our team we include on-campus professionals in education, policy and planning, and also in teaching and learning support from the Office of Information Technology (OIT). This broader team has allowed us greater support for design and implementation of active learning pedagogy and technology. During each semester we have a variety of team meetings. The complete team (faculty, GTAs, and UTAs) meets twice each semester for goal setting, team building, and reflecting on the success of the semester. In addition we have weekly UTA meetings and GTA meetings. (Due to the large numbers of UTAs and GTAs, as well as scheduling restrictions, one teaching assistant meeting was not feasible.) One of the faculty instructors attends the UTA meetings. This faculty representative reports on UTA activities at the weekly GTA meetings that are attended by GTAs and all course 
instructors. The faculty instructors meet alone or with education and OIT faculty team members once or twice a semester or on an as-needed basis.

The GTAs have nontraditional roles with regard to their participation in course development and planning. They bring their own science expertise, their recent experiences as students, and their role as liaison to the students. For facilitation of peer learning in student online discussions, we added UTAs to our team. They serve a role similar to students in PLTL (PLTL Workshop Project, 2004). Students eligible to serve as UTAs have completed our course with an "A" or "B" grade and receive course credit for their participation.

\section{Content}

The ALCF was designed to support a shift in student activity away from memorization and toward activities that promote discovery of information needed to solve problems. Along with others (Cronin-Jones, 2003; Wood, 2003), we feel that the lecture presentation serves an important role in science education, but like Weld (2002), we think that the lecture is most appreciated by a student who is prepared. Scientists listen to detailed research seminars (lectures) and appreciate the content because of their prior knowledge of the field, their understanding of context, and their interest in solving a research problem. In our framework, the lecture is placed in the context of a research seminar given by an expert. The students are put in the role of a scientific researcher through the use of three course case studies. Formal lectures given in the lecture hall by faculty instructors and shorter lectures given in lab by the GTAs are used to provide content and opportunities to learn standard protocols that would be useful in addressing case-study problems and course assignments. Thus the delivery of content still occurs via the lecture format in the lecture and lab periods. However, students are prepared for this delivery in a manner not found in the traditional course design. They are armed with a context (from the case study) and challenged with rich and interesting problems (associated with the case study) that they will need content to address. In addition, students are encouraged to seek content from the textbook and from their own research (links to online databases are provided). The lecture thus becomes more similar to the research seminar, where students are in the position of needing to know information to address weekly assigned case-study problems. The ALCF continues to include the lecture as a prominent course component, but it is placed into perspective by linking the presentation to case studies and associated learning goals (see Figure 1 and Table 1). The role of the faculty in the lecture hall remains very similar to their role in the traditional course format, but as a result of the linkage of the lecture material to active-learning course components (see later examples), the lecture experience is seen in a new light by faculty and students alike.

\section{Relevance of Science}

Case studies provide a tool to present context and rich problems and to engage students in active learning (Camill, 2000). Each one of our case studies focuses on a major scientific research area: Case 1, the search for microbial forms of extraterrestrial life; Case 2, the use of biotechnology for the development of transgenic crops; and Case 3, the micro-
Table 2. Case-study learning: the Case/PAK mode

The Case/PAK mode employs an interrupted case (Herreid, 2001) and is taught by a directed case method (Cliff and Curtin, 2000) where students submit answers online. A case is presented in three modules accompanied by three sets of problems and associated data. We refer to the problems as PAK problems to highlight their purpose to the students. Students receive participation points for applying learned knowledge to case-study problems. There are five phases to this approach:

Phase 1:

- The case and the problems are briefly introduced in the lecture setting and then presented in full detail with linked resources on the online site.

Phase 2:

- Students submit solutions online for each set of problems by a specified due date. Students are expected to print their submissions and review/edit during discussion (Phase 4).

$>$ Phase 3:

- The instructor accesses the online environment to review student responses. In a manner similar to JITT (Marrs and Novak, 2004), the due date for student responses is midnight prior to the lecture period in which responses will be discussed (Phase 4). From the assessment of the student responses, the instructor establishes discussion questions that will target problem areas.

$>$ Phase 4:

- For one lecture period each week, $20 \mathrm{~min}$ is devoted to case study discussion:

- Students are given a few minutes to discuss their PAK solutions with neighbors and receive peer feedback.

- Faculty instructor leads open class discussion of PAK solutions.

- Faculty asks questions to probe misunderstandings revealed by prior reading of student PAK responses.

- Students participate in a discussion according to a T-P-S type of model (Allen and Tanner, 2002); the final step is open discussion led by the faculty instructor.

$>$ Phase 5:

- Students self-assess their solutions to case-study problems and learn content, vocabulary, and skills that will be formally assessed on lecture exams.

biology/immunology of a common infectious disease (see Table 1). The topics are rich, not only in their science, but also in their broader social implications. Each case study provides a story line for lectures, lab experiments, problem sets, and assignments, and serves as a venue to highlight research experiences and expertise of the faculty.

\section{Textbook}

When the emphasis of the course is shifted away from content delivery to active student learning, the role of the textbook changes. As a general microbiology course, the learning goals reflect the curriculum established by the 
Table 3. Case-study learning: the online discussion mode

The online discussion mode employs a dilemma case (Herreid, 1994). A case study that poses a multifaceted dilemma serves as the centerpiece for an extended, online discussion that culminates in a group-authored report.

1. Choose a dilemma case with a set of distinct issues for student discussion.

We have authored a case called "The Farmer's Dilemma" that highlights the controversy surrounding the development and use of transgenic plants. In addition to demonstrating knowledge of bacterial genetics and biotechnology, students must research issues relevant to a farmer's dilemma: Should he plant transgenic corn carrying a gene for the Bt CRY toxin (Nester et al., 2002)?

This case has three distinct issues for student discussion:

- Issue 1: Is transgenic Bt corn safe for human consumption?

- Issue 2: Is transgenic Bt corn safe for the environment?

- Issue 3: Is there a market for transgenic Bt corn?

2. Establish student teams for online discussion and for report writing.

We establish our teams within the lab sections. Within one lab section, students are assigned to lab teams of three for lab work. These lab teams serve as the report writing teams for our use of the online discussion mode. The Jigsaw method of grouping (Tanner et al., 2003) is used to form the discussion teams: one student is selected from each lab team to form six discussion teams.

3. Assign each online discussion team one case issue.

We have three discussion groups per lab section. Each group receives one of the three major issues for discussion.

4. Establish private discussion areas within WebCT for each discussion team.

5. Post the case study and directions for discussion online.

- Each student must make four postings: two factual postings with references and two comment postings that further discussion.

- A UTA monitors the online discussion.

6. After a prescribed period ( $2 \mathrm{wk}$ ), signal students to meet in lab sections to discuss, face to face, the facts, controversies, and questions discovered during the online discussion.

7. Signal students to re-sort into report-writing groups.

Each group will now comprise three students, each expert in one of the three case study issues 1, 2, or 3.

8. Signal students to write a group-authored report that highlights their understanding of the learning goals, as well as the facts, questions, and controversies surrounding the dilemma. The report should culminate in a recommendation regarding the resolution of the case-study dilemma.

Our report-writing groups construct reports that address the "Farmer's Dilemma." The report requires students to analyze concepts learned in lecture, in lab, and during the online discussion, and to synthesize the information into a coherent and well-supported recommendation for the farmers.

American Society for Microbiology (ASM, 1994). In our course design, students are required to buy a text and reading assignments are given. However, the text does not serve to drive the course syllabus and represents only one source of information. Students also are encouraged to consider the lecture and their own research as sources of information. They are directed to current papers and online journals via an online course library page (BSCI 223 Course Library Page, 2004). By encouraging students to seek information from multiple sources, we hope to instill skills for lifelong learning.

\section{Tools}

Teamwork and technology are the major tools that drive the active learning in the ALCF. The instructors work as a team to create linkages between all course components. Students work in teams for various active learning activities. Students participate in formal teams for lab work and for structured team assignments (see examples of case-based learning, Tables 2 and 3). Students work with informal teams for T-P-S discussions in lecture. Formal teams are set up within the lab section. GTAs establish teams of three students in the lab. Students are assigned to a team based upon their voluntary responses to various questions about their background in science, knowledge of technology, experience in a research lab, address, race, gender, and grade point average. The teams are designed to be diverse, mimicking the structure of a team of scientists: each member brings a unique perspective and a special expertise to the group effort. For the reportwriting portion of the online discussion mode of case-study learning (Table 3), student teams of three are re-sorted according to the Jigsaw method (Tanner et al., 2003) to provide teams of six students (see later discussion of the online discussion mode and Table 3). The teams of six students are randomly chosen, but within a lab section of 18 students, each team of six has one representative from each team of three. Our rationale for incorporating teamwork into the student experience comes from reports that teamwork increases student retention of knowledge and hones critical thinking skills (McInerny and Fink, 2003). Also, we realize that when scientists work, they collaborate with others. Our 
hope is that by working in teams, students will learn social skills that will support their success as practicing scientists.

We have described already how technology serves as a tool to link the learning environments, the people, and the pedagogical mission of the course. Further, technology is used to support course management, to provide opportunities for communication, to direct students to online resources, and to offer active-learning opportunities (Table 4). The password-protected course management system that is supported at the University of Maryland is WebCT (WebCT, 2004). All information posted in the online environment is available at all times of each day and evening. Faculty members add information and post timely announcements to the site at least once each week. Various course quizzes and surveys are programmed to become available and then to close at set dates. The calendar tool of WebCT alerts students to upcoming assignments. The open discussion is available to students at all times and is monitored by faculty, GTAs, and UTAs on a daily basis. Using technology to support course management provides us great flexibility. We may distribute materials at our convenience, and students may access the online environment at their convenience. There is an online record of all activity, and course materials can be updated easily. We also hope that by using the online environment, we are giving students practice in using technology, a tool that is becoming increasingly valuable to the practicing scientist.

\section{Active Learning}

In the ALCF, the case study serves as the anchor for all learning activities. For each course module (see Table 1), a case is presented online. The lectures and the lab exercises for the module speak to problems associated with the case study. We have designed two modes for students to work with case studies. Table 2 describes the Case/PAK mode, which is the cornerstone method used in the ALCF. In each course module, the Case/PAK mode of case-based learning engages students in problem-solving, listening, research, discussion, and presentation. Students are involved online (reading the case, reviewing relevant course PowerPoint presentations, researching solutions to case questions, and submitting those solutions for review by faculty). Students are involved in

Table 4. Activities in the ALCF

\begin{tabular}{|c|c|}
\hline Activities & Description of the active learning component \\
\hline 27 lectures & $\begin{array}{l}\text { Students are encouraged to be active listeners during the formal lecture. During PAK } \\
\text { discussions that occur during the lecture period, students are encouraged to participate via } \\
\text { T-P-S discussions. 25/100 minutes per week is dedicated to in-lecture discussion. }\end{array}$ \\
\hline 3 lecture exams & $\begin{array}{l}\text { Students are required to answer questions designed to assess critical thinking using } \\
\text { questions similar to PAK questions. }\end{array}$ \\
\hline 14 lab exercises & $\begin{array}{l}\text { In the lab period students work in teams to learn standard protocols and apply these to } \\
\text { case-study related concepts and problems. For each lab exercise students must complete } \\
\text { a short data sheet and accompanying questions. Inquiry labs require students to complete } \\
\text { detailed reports. }\end{array}$ \\
\hline Online environment & $\begin{array}{l}\text { Students may access this additional site for learning and communication: } \\
\text { available } 24 \mathrm{~h}, 7 \mathrm{~d} \text { each week. }\end{array}$ \\
\hline Online open discussion area & $\begin{array}{l}\text { Students enter common discussion area to ask questions that are answered by other students } \\
\text { or a member of the teaching team. }\end{array}$ \\
\hline Small group online discussion & $\begin{array}{l}\text { For the online discussion mode of case-study learning, students participate in one online } \\
\text { discussion per semester. The required number of posts for the assignment is } 24 \text { per group } \\
\text { of six students. }\end{array}$ \\
\hline Online lecture-related material & $\begin{array}{l}\text { For every lecture PowerPoint slides, links to further information, vocabulary lists are posted } \\
\text { for students to review or print. }\end{array}$ \\
\hline Online lab-related material & Students access lab protocols available on line as pdf documents. \\
\hline Online lab review quizzes & $\begin{array}{l}15 \text { quizzes with a total database of } 500 \text { questions and } 350 \text { lab images are available for the } \\
\text { students to self-assess learning of lab concepts. Unlimited number of attempts allowed. }\end{array}$ \\
\hline Opportunity for student presentation & $\begin{array}{l}\text { Each lab group of three publishes one Web page each semester, writes one group-authored } \\
\text { report, and gives one oral presentation. }\end{array}$ \\
\hline Case study and associated PAK questions & $\begin{array}{l}\text { Three case studies each with three sets of PAK questions are posted per module. Students } \\
\text { must log in to answer three questions each week. }\end{array}$ \\
\hline Feedback to students: grade posting & Students may access online grade book to review grades that are updated weekly. \\
\hline Home page announcement area & $\begin{array}{l}\text { Students receive up-to-date information each time they log into the online environment. } \\
\text { This a weekly posting of an image and a question related to lab work. }\end{array}$ \\
\hline Technology support & $\begin{array}{l}\text { Students complete technology quiz and pdf tutorial handout for Web page construction, } \\
\text { and have access to a library resource page with links to online journals, genomic databases, } \\
\text { and Web sites. }\end{array}$ \\
\hline Online student satisfaction survey & Students complete end of semester survey. \\
\hline
\end{tabular}


lecture and in lab (listening for relevant information to apply to case-study issues, and discussing case-study responses; see Table 2). This mode requires time in lecture and in lab for case-study discussion. With limited time for formal lectures each week, there was concern that by using some of our lecture period for discussion we would not have the time to cover the entire course content. The Case/PAK mode addresses this. Some content coverage is shifted to student learning. Some topics related to PAK problems are researched by students without any prior introduction in lecture. Students relay their understanding of the content in PAK solutions. Faculty, in reading students' PAK responses, can determine what content needs further coverage in a formal lecture and what content and concepts the students have learned through their own work. Also, during PAK discussions in lecture and in lab, students are encouraged to ask questions about any content that they did not fully understand. Our hope is that by using this mode of teaching, we will instill in our students a sense of responsibility for their own learning.

The use of technology to review PAK submissions is an excellent example that illustrates how technology supports active learning in a way that would not have been feasible in the absence of technology for a large-enrollment course such as ours. For PAK review, students individually submit solutions to PAK problems online by a set due date. The opportunity to submit is controlled by the technology. The PAK problems are available within the WebCT quiz tool. After the submission deadline, student submissions to an individual problem can be tabulated within WebCT or can be downloaded to a spreadsheet. The submissions (up to 300 in our class) then can be scanned by the faculty lecturer for accurate use of terms, understanding of major concepts, misconceptions, and use of references.

Table 3 describes our online discussion mode of case-study learning. The discussion of broad science, social, and economic issues that are current and controversial and pose a dilemma may be addressed using this mode. We use the online discussion mode for the assignment in Module 2 (Table 1). Our case, "The Farmer's Dilemma," poses issues relevant to the safety and marketability of genetically modified corn. Students are given the charge to research current information, to discuss and to assess the information critically, and then to craft a report that addresses a casestudy dilemma. To allow for extended small group discussions without the requirement of a set time or meeting place (both of which are very difficult to arrange for a large class), this mode employs an online discussion space. The use of the online environment provides convenience to the students, easy access to online databases, a method for sharing of resource information (students provide links to reference sites), and a record of the conversation. Faculty and teaching assistants can observe the conversation unobtrusively and later review the record for evaluation purposes. When using the "Farmer's Dilemma" case study for this online discussion mode, students role-play as scientific consultants who have been hired by a set of farmers grappling with issues relating to the planting of transgenic crops. Any dilemma case would be appropriate for using this method of case-based learning. Many cases can be found in published databases such as the National Center for Case Study Teaching in Science (University of Buffalo, 2004). For our specific use of the online discussion mode, three issues relevant to the case dilemma are discussed. The number of issues is dictated by our lab enrollment of 18. For the online discussion, one student from each lab team of three participates in an online discussion team of six students. Each online discussion team investigates one case issue. After the online discussions are complete (Table 3), students return to the lab environment for an open face-to-face discussion of the case-study issues and for report writing. Lab teams of three write the final dilemma resolution reports. According to the Jigsaw method of group work (Tanner et al., 2003), after re-sorting the lab teams, each team has an expert on each of the three case issues. For the online discussion, students are expected to investigate and discuss relevant facts, controversies, and questions found in online resources. Students are encouraged to consider and to weigh information found in peer-reviewed and non-peer-reviewed sites. Our goal with this mode of case-study learning is that students will become engaged in learning course content as they see the relevance of the content to real-world problems. Further, we hope that by giving students roles and by providing students a context in the form of case studies, the class-related activities are much closer to those of a scientist operating in the real world, compared with activities required of students in the traditional lecture/lab/exam course structure.

\section{ASSESSMENT AND EVALUATION}

Our goal was to respond to the call to research universities to transform courses from lecture centered to student centered. To reach this goal we designed a framework to support active learning in our large-enrollment introductory microbiology course. By taking the approach to restructure our course, questions arise as to whether the new structure achieves intended goals and improves the learning of its students. The teaching team has approached assessment and evaluation in a multi-layered manner in order to determine the functioning of individual course components and the preparation of students for upper level courses. This effort has included analysis of student participation in and student perception of active-learning tasks, student performance in the course, student perception of active learning as measured in a university course evaluation, and student retention of course learning.

\section{Student Participation in and Perception of Active- Learning Tasks}

Our goal was to add active learning in a way that would be effective and manageable for a large-enrollment class and that would introduce skills valuable to a research scientist. We incorporated published active-learning strategies into a construct that allowed a philosophical shift in the course from passive lecture-centered to active student-centered learning. Prior to our course transformation the activities of the students were listening in lecture, writing notes, asking an occasional question, completing exams, and working on labs that offered exercises mostly driven toward an expected result. With the ALCF in place, activities available to the students have increased dramatically (Table 4). Table 5 shows student participation in the various course activities during the spring and fall of 2004. Different faculty instructors served as course lecturers in the spring of 2004, in the fall of 2004 
Lecture 1, and in the fall of 2004 Lecture 2. An additional faculty instructor served as the lab and online environment coordinator and was present in this role in the spring of 2004 and the fall of 2004. We noted a variance in student participation in the online open discussion area and in the frequency with which the students accessed the online learning environment (Table 5). Particularly in the fall of 2004 , the frequency with which students accessed the online environment was reported by $24 \%$ of the students to be at least once every other day, compared with $93 \%$ and $91 \%$ reporting access once every other day in the fall 2004 sections. The activity of the course instructor in the WebCT space may affect the activity of the student activity in that space. Also, in the spring of 2004, the calendar tool of WebCT was used for major course deadlines such as exam dates. But in the fall of 2004 the use of the calendar tool was increased such that every course activity was announced. The increased use of the calendar tool in the fall may explain the increase in student access to the online space in the fall of 2004.

Like Witham et al. (2002), we have received very positive feedback from our students regarding the addition of the online course management system to our course. In the fall of 2004, 340 students responded to a course survey. Students were asked what they liked about the use of WebCT in BSCI 223 General Microbiology. The majority of the students (209 responses) indicated that they liked the use of WebCT, because of the access that it provided to course materials. These students commented about the availability of course materials $24 \mathrm{~h}$ a day, seven $\mathrm{d}$ each week. There were 75 students who indicated that the option to communicate with other students and with the teaching team through the online environment was the most valuable aspect of our use of WebCT. Forty-one students commented on the ease of using the online environment, and 46 students noted that the use of the online environment to provide organization to the course was of great value. Only 14 students responded with negative comments about the use of WebCT. These students found the use of the online environment a hassle that made them a slave to the computer.

To determine how our students perceived the use of case studies in our course, students were asked, "How useful did you find case studies in helping you see the relevance of course material?" Of the 340 students in the combined lecture sections of fall 2004, 59 students chose "One of the most useful parts of the course," 178 students chose "Very helpful," 113 students chose "Somewhat helpful," 11 students chose "Not very helpful," and eight students chose "Not helpful at all." In the same survey, students were asked the open-ended question, "What do you like about the use of case studies in BSCI 223 (General Microbiology)?" Of the 339 students responding, 123 students indicated that they liked how cases helped them to learn/think about/apply course concepts, 128 students described how cases allowed them to see the realworld relevance of course concepts, and 79 students reported that the case studies made the course concepts more interesting or more engaging. Nine students indicated that the case studies had no value and that the case-study work was either busywork or too much work in general.

Table 5. Data regarding student use of the online course environment

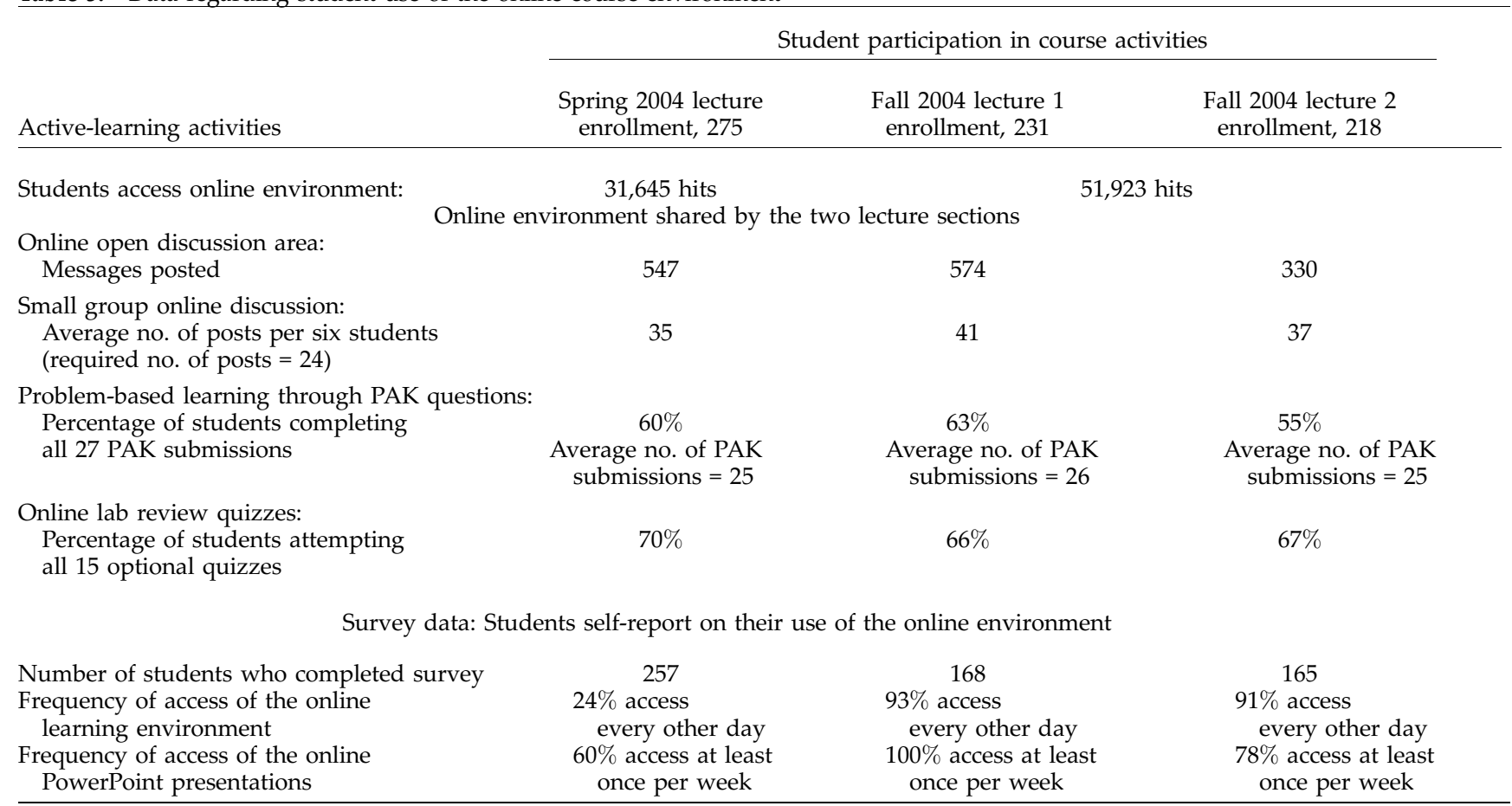

Data were either collected by counting numbers of student hits/submissions to various activities, or through self-reporting by students in a survey at the end of the semester. 
Table 6. BSCI 105 as taught with the ALCF; the course was divided into three modules each anchored with a case study and PAK problems

\begin{tabular}{|c|c|c|c|}
\hline Learning goal topics & Case study & Lecture & Lab \\
\hline $\begin{array}{l}\text { Module 1: The process } \\
\text { of science }\end{array}$ & $\begin{array}{l}\text { Case 1: Fictional story based on an actual letter } \\
\text { to the editor of The Washington Post. The } \\
\text { author of the letter decries the environmental } \\
\text { impact of a new designer house. } \\
\text { PAK } 1.1 \\
\text { Hypotheses and experimental design } \\
\text { PAK } 1.2 \\
\text { Acid rain and pH }\end{array}$ & $\begin{array}{l}\text { Lecture set } 1 \\
\text { Lecture 1: The scientific method } \\
\text { Lecture 2: Chemistry } \\
\text { Lecture 3: Water and } \mathrm{pH}\end{array}$ & $\begin{array}{l}\text { Relevant lab work: } \\
\text { Lab 4: Formulating and } \\
\text { testing hypotheses } \\
\text { Lab 5: Developing a } \\
\text { scientific protocol }\end{array}$ \\
\hline Module 2: Metabolism & $\begin{array}{l}\text { Case 2: Fictional story of a group of students } \\
\text { who are concerned about the bizarre diet } \\
\text { regimens followed by a housemate. Students } \\
\text { use the Web to research various diet claims. } \\
\text { PAK } 2.1 \\
\text { Enzyme/substrate interaction, impact of } \mathrm{pH} \text {, } \\
\text { chemical composition of fats } \\
\text { PAK } 2.2 \\
\text { Entropy, glycolysis, gluconeogenesis } \\
\text { PAK } 2.3 \\
\text { Aerobic respiration, anerobic respiration, } \\
\text { fermentation }\end{array}$ & $\begin{array}{l}\text { Lecture set 2: } \\
\text { Lecture 13: Free energy and } \\
\text { catalysis } \\
\text { Lecture 14: Metabolism and } \\
\text { ATP } \\
\text { Lecture 15: Enzyme kinetics } \\
\text { Lecture 16: Glycolysis } \\
\text { Lecture 17: Kreb's cycle } \\
\text { Lecture 18: Electron transport } \\
\text { chain } \\
\text { Lecture 19: Fermentation } \\
\text { versus respiration }\end{array}$ & $\begin{array}{l}\text { Labs } 6 \text { and 7: Enzyme } \\
\text { kinetics } \\
\text { Lab 8: Fermentation/ } \\
\mathrm{CO}_{2} \text { production }\end{array}$ \\
\hline Module 3: Genetics & $\begin{array}{l}\text { Case 3: Fictional story of two students discussing } \\
\text { the use of recombinant DNA techniques } \\
\text { in medicine and forensics. } \\
\text { PAK } 3.1 \\
\text { Information flow, implications of mutations } \\
\text { on protein structure } \\
\text { PAK } 3.2 \\
\text { Gene organization and expression } \\
\text { PAK } 3.3 \\
\text { Cloning a eukaryotic gene, RLFP, PCR }\end{array}$ & $\begin{array}{l}\text { Lecture set 3: } \\
\text { Lecture 23: Molecular basis } \\
\text { of inheritance } \\
\text { Lecture 24: DNA replication } \\
\text { Lecture 25: From gene } \\
\text { to protein } \\
\text { Lecture 26: Transcription } \\
\text { Lecture 27: Maturation of RNA } \\
\text { Lectures } 28 \text { and 29: Translation } \\
\text { Lectures } 30 \text { and 31: Control } \\
\text { of gene expression } \\
\text { Lectures } 32 \text { and 33: Genetic } \\
\text { engineering }\end{array}$ & $\begin{array}{l}\text { Lab 10: Isolation of DNA } \\
\text { Lab 11: Electrophoresis } \\
\text { of DNA } \\
\text { Lab 12: Searching the } \\
\text { genome with BLAST }\end{array}$ \\
\hline
\end{tabular}

\section{Student Performance}

Student assessment for purposes of a course grade remains the role of the course instructors and the GTAs. We have shifted from our previous grading plan (three objective exams, lab quizzes, one lab report, and a final lab practical) to a plan that reflects the new philosophy of the course. The majority of the grade depends on the lecture exams, but the exam questions are designed to follow the format of the PAK problems and require students to demonstrate understanding of content, use of vocabulary, and ability to think critically. Assignments 1, 2, and 3 are significant projects that require students to work in teams, to respond to casestudy challenges and to produce group-authored reports (see Table 1). As in research presentations, these reports require that student teams demonstrate understanding of concepts and appropriate use of scientific terms, as well as present a cohesive response to a case-study problem. Teamwork was added to encourage student discussion and learning and to reduce the workload for the instructors. Our team projects use groups of three, thus reducing the work of feedback and assessment by instructors by twothirds. Short lab reports and objective assessments (lab midterm and lab final) that test understanding of lab protocols and ability to interpret lab data make up a portion of the grade and keep students on task in the lab. PAK responses are given points for participation. The course design emphasizes that good student performance is linked to participation in the various modes of active learning. Even though the novel course design is more demanding in terms of effort and timely execution, there is no evidence that student grades are lower than in the traditional version of the course. Also, although we have taken time during the lecture period for active-learning activities, the breadth of material included on lecture exams has not changed as a consequence of our new course philosophy. The content covered continues to be similar to that covered prior to our shift to ALCF. What has changed is that not all content topics are covered in lecture, as once was the case. Some content topics are covered as students read case-study problems and search for answers on their own, or as students work through interactive labs. We assess the need to explain topics that are not addressed in formal lecture by reading PAK submissions and lab reports. Using the ALCF, one of our goals has been to shift some of the responsibility for content coverage to the students. By doing this we can include active-learning opportunities within our limited lecture time without sacrificing course content goals. 


\section{University Course Evaluation}

In the fall of 2002, our course (General Microbiology, BSCI 223) was evaluated by the University of Maryland General Education (CORE) committee as part of a periodic review process. In 1993, our course scored close to other lecture/lab life science CORE courses taught at the university. After implementation of the ALCF, we received significantly higher scores on the two questions that assessed active learning and the understanding of the process of science. The comparison was to all Life Sciences Lab courses reviewed over time. Mean scores were compared. For the question, "To what extent has this course helped you understand the method of study or observation, collection, and analysis of data characteristic of this field?" BSCI 223 scored $11.26 \%$ higher than the score for all Life Science Lab courses. For the question, "To what extent has this course given you opportunities to participate actively in the learning process through discussions, small group work, laboratories, etc.?" BSCI 223 scored $12.63 \%$ higher. Both values are significant at the $5 \%$ level.

\section{Retention of Course Learning}

This teaching team is working on a Howard Hughes Medical Institute-supported project with other colleagues from the Department of Cell Biology and Molecular Genetics to investigate student-learning gains and student ability to transfer knowledge gains from our introductory microbiology course to advanced microbiology courses. This project involves the development of a detailed pretest and post-test for major microbiology concepts. These tests will be used to track the learning and retention patterns for groups of students as they move from our introductory course to the advanced microbiology courses. This new initiative will be a multi-year, multi-course project that will help us assess the impact that the implementation of ALCF in our introductory microbiology course has had on long-term student learning.

\section{CONCLUSION}

The design and implementation of the ALCF for our largeenrollment course was a complex undertaking. However, the outcome has been very promising. We have increased the active-learning component of the course dramatically. To do so, we have employed a teaching team and the use of technology. We have used case studies as our pedagogical focus. Students have been involved in two modes of casestudy learning. We have shifted learning away from a lecture- and textbook-driven course toward a course where an emphasis is placed on student investigation of case-study problems that require learning from multiple sources that include lecture and the textbook, but also include outside sources and lab. Student surveys indicate that students appreciate the use of technology to organize the course and the use of case studies to provide context. They feel that BSCI 223, when taught using the ALCF, does a good job in engaging them in learning.

The course faculty considers the institution of the ALCF in General Microbiology a success, but it has required considerable faculty time to build a library of teaching resources (e.g., case studies, PAK questions, linked laboratory experiences) and to put into place the mechanics for the transition. But the process has been rejuvenating for us. Working together as a team and reflecting on input from our students, GTAs, and UTAs have infused us with a new excitement for teaching. Incorporating case studies gave us opportunities to include in our teaching information about our research programs and current topics in our field. Although developing the framework required an increased time commitment, reflecting over the last few years, we feel that the outcome was worth the investment. By working together, we shared responsibility for the work required to reinvent our course. Because of the varied expertise within our team, the development phase and now the implementation phase of the ALCF benefit from our commitment to collaboration.

Another benefit of our redesigned course has been the evaluation of the roles of teaching assistants. In the preALCF version of our course, graduate students acted primarily as lab supervisors. In the revised course, GTAs operate as partners with the faculty in carrying out the course goals. The enhanced role of the GTAs provides them with opportunities to learn about the theory and implementation of various education strategies and to see faculty members as teachers. We have encouraged our graduate students to take advantage of the University of Marylandsponsored University Teaching and Learning Program (UTLP, 2004) to earn a citation in teaching as they work on course projects and consider how science education will be part of their future career. UTAs served to support the online discussion. Each UTA worked with three online discussion groups and coached the groups through the research and discussion process. The feedback from the UTAs has been very positive. They find their role very rewarding and appreciate the opportunity to see education from the faculty point of view.

Our goal with this work was to implement a structure that did not require additional significant or sustained funding. Our progress has been dependent upon the support readily available at our university. University grants have funded the purchase of computer software and attendance at meetings. Our OIT and the Center for Teaching Excellence have provided expert advice and support. A College of Life Sciences-funded program (Undergraduate Technology Apprentice Program [UTAP], 2004) has afforded us with two trained undergraduates each semester to help with our technology needs. Furthermore, our course development evolved though discussions with colleagues at education meetings supported by the ASM Board of Education, the NRC, the National Science Foundation, Project Kaleidoscope, and the National Center for Case Study Teaching in Science. To further ease the work of the teaching team and to ensure the success of our conceptual framework, collaboration between different institutions with the sharing of methods and teaching materials will be essential. Facilities for this sharing are already in place through the various digital libraries (for example, National Science Digital Library, MicrobeLibrary, Merlot, and Bioscience Education Network).

With the ALCF now in place within General Microbiology for three semesters, we can report on the commitment required for adoption of the plan. After the initial investment of learning the use of the course management system and of writing case studies or choosing case studies from a database such as the National Center for Case Study Teaching in Science, there is some cost to running an activelearning course that is dependent on teamwork and technology. Working as a team requires that faculty 
members relinquish some control over the course and requires that faculty members participate in weekly team meetings and collaborate on projects. In addition to meetings, to implement the ALCF, faculty time is spent on usual course activities such as lecture preparation and test design. In the traditional course design, lecture writing and test preparation are time-intensive endeavors. Often the challenge of preparing good lectures and test questions begs the identification of a story or example to provide context. We have found that the links to case studies intrinsic to the ALCF make these tasks easier. With lecture writing requiring less challenge, faculty time is available to prepare for in-lecture discussions. Faculty members review PAK responses and include the misunderstandings and misconceptions in the design of lecture preparation and inlecture discussion questions. This is the most challenging aspect of adoption of the ALCF. Once each week, faculty members must spend time prior to the designated lecture period reviewing student responses. Although this step takes time, we feel that the information reaped from reading student responses well outweighs the added commitment. Because we are using a JITT method (Marrs and Novak, 2004) for discussion of case-study problems, like others using JITT, we truly can sense the pulse of the class in a manner not previously available to us. For the lecture discussion phase of the Case/PAK mode, providing feedback to students concerning their PAK responses and addressing students' misconceptions of course concepts revealed in PAK responses, faculty comfortable with lecturing to large groups must learn to promote discussion. Engaging students to speak in the lecture setting is a great hurdle for many faculty members. We have used the T-P-S method (Allen and Tanner, 2002) as one mode to encourage participation. A last requirement for faculty time comes from the use of technology in the course. Time is spent by faculty monitoring questions posted on the online environment or posting lecture and lab information to this site. The time requirement for the faculty, however, is variable and directly relates to faculty interest in technology. Students, UTAs, and graduate students can respond to the majority of questions posted, and GTAs or other technology support persons can be assigned the role of posting course information to the online course environment. We used undergraduate students trained in our UTAP (UTAP, 2004) for many technology-related tasks. However, data from a three-semester preliminary study (Table 5) suggest that faculty lecturer involvement within the WebCT space will affect student activity in that space.

\section{Adapting the Framework to Other Courses}

In the past year, one of our faculty team has been reassigned to the teaching of one section of our large-lecture introductory biology course (BSCI 105). That course had been taught in the traditional manner: three 50-min lectures and a separate lab. In her first semester teaching that course, she began the adoption of the ALCF. WebCT was added, lecture content was linked to lab topics, and case studies and PAK problems were instituted. Case studies were used to cover the three basic modules of the class (Table 6). After one semester, the feedback has been positive from both students and faculty. Eighty percent of the 250 students participated in all three Case/PAK modules, thus significantly increasing the active-learning aspect of the course. This success suggests that the ALCF developed using an introductory microbiology course as the test case is indeed a flexible framework that can be adapted to meet the needs of other largeenrollment science courses.

\section{This Project Placed in a National Perspective}

Science education research reported in the NRC publications "How People Learn" (2000), Bio2010 (2003), as well as the Project Kaleidoscope report "What Works, What Matters, What Lasts" (Narum, 2004), calls us to evaluate our teaching and to completely reformat our courses. "Innovative introductory science courses address an important national need," claimed Dr. George Langford, a key member of the National Science Board, in the report "The Science and Engineering Workforce. Realizing America's Potential" (National Science Board, 2003). As Langford has pointed out, our introductory science courses act more as filters than as pumps. More often than not, students experience science as the dry memorization of facts without any relevance to careers in which they wish to spend most of their working lives. Our course design has given us the opportunity to add to our class strategies that have already been demonstrated to be successful, but which were previously out of our reach because of our large class enrollment, time limitations, and course management needs. Technology and a teaching team support our ALCF. By instituting the framework, we were able to shift the focus of the course from didactic to studentlearning centered. The use of case studies and problemsolving as a platform for active learning gave students the opportunity to conceptualize information and to practice skills that will be useful in their future careers as practicing scientists.

\section{ACKNOWLEDGMENTS}

The authors acknowledge financial support from the following sources at the University of Maryland: Department of Cell Biology and Molecular Genetics, College of Life Sciences, Office of Information Technology, and the Scholarship of Teaching and Learning Program. A National Science Foundation grant provided research for the development of a collection of case studies that are being used in our biology courses.

The authors would like to thank UTAP students Anne Tsang, Karen Lew, Allyson Morman, Maria Panglao, Fasika Woreta, Kathy Shahrokh, and Sonia Sharma for hours of dedication put toward the establishment and maintenance of the BSCI 223 online space, and enthusiastic GTAs, UTAs, and BSCI 223 students whose feedback encouraged and guided us. Special thanks to University of Maryland librarian Bonnie Chojnacki for developing our course-specific library page, and Web designer Anne Tsang for expressing our course vision in the image displayed in Figure 1.

\section{REFERENCES}

Allen, D.E. (1996). Bringing problem-based learning to the introductory biology classroom. In: Student-Active Science: Models of Innovation in College Science Teaching, ed. A.P. McNeal and C. D'Avanzo. Philadelphia: Saunders College Publishing, 259-278.

Allen, D.E., and Tanner, K. (2002). Approaches in Cell Biology Teaching. Cell Biol. Educ. 1, 3-5. http://www.cellbioed.org/articles/ vol1no1/article.cfm?articleID=2 (accessed 14 July 2004).

American Society for Microbiology (ASM). (1994). ASM's Curriculum Recommendations: Introductory Course in Microbiology. http:// 
www.asm.org/Education/index.asp?bid=10051 (accessed 14 July 2004).

American Society for Microbiology (ASM). (2004). Microbe Library. http://www.microbelibrary.org (accessed 28 July 2004).

Bioscience Education Network (BEN). (2004). http://www. biosciednet.org (accessed 28 July 2004).

BSCI 223 Course Library Page. (2004). http://www.lib.umd.edu/ MCK/bsci223.html (accessed 28 July 2004).

Camill, P. (2000). Using journal articles in an environmental biology course. J. Coll. Sci. Teach. 30(1), 38-43.

Cliff, W.H., and Curtin, L.N. (2000). The directed case method: teaching concept and process in a content-rich course. J. Coll. Sci. Teach. 30(1), 64-66.

Cronin-Jones, L.L. (2003). Are lectures a thing of the past? J. Coll. Sci. Teach. 32(7), 453-457.

Handelsman, J., Ebert-May, D., Beichner, R., Bruns, P., Chang, A., DeHaan, R., Gentile, J., Lauffer, A., Stewart, J., Tilghman, S.S., and Wood, W.B. (2004). Scientific teaching. Science 304, 521-522.

Herreid, C.F. (1994). Case studies in science: a novel method for science education. J. Coll. Sci. Teach. 23(4), 221-229. Also available online at http://ublib.buffalo.edu/libraries/projects/cases/teaching/ novel.html (accessed 28 July 2004).

Herreid, C.F. (1998). What makes a good case? The case study. J. Coll. Sci. Teach. 27(3), 163-165.

Herreid, C.F. (2001). Mom Always Liked You Best: Examining the Hypothesis of Parental Favoritism-Prologue: The Interrupted Case Method. ublib.buffalo.edu/libraries/projects/cases/coots/ coots_prologue.html (accessed 28 July 2004).

Johnson, M.C., and Malinowski, J.C. (2001). Navigating the active learning swamp. J. Coll. Sci. Teach. 31(3), 172-177.

Lux, M.F. (2002). An Activity-Based Format Increased Student Retention in a Community College Microbiology. Microbiol. Educ. 3(1), 12-17. http://www.microbelibrary.org/FactSheet.asp?SubmissionID=1158 (accessed 28 July 2004).

McInerney, M.J., and Fink, L.D. (2003). Team-based learning enhances long term retention and critical thinking in an undergraduate microbial physiology course. Microbiol. Educ. 4, 3-12.

Marrs, K.A., and Novak, G. (2004). Just-in-time teaching in biology: creating an active learner classroom using the Internet. Cell Biol. Educ. 3, 49-61.

Merlot. (2004). http://www.merlot.org (accessed 28 July 2004).

Narum, J. (2004). Project Kaleidoscope, Volume IV: What Works, What Matters, What Lasts. Considering How Students Learn: A PKAL Essay on The Learner Centered Environment. http://www.pkal.org/template2.cfm?c_id=992 (accessed 28 July 2004).
National Research Council. (2000). How People Learn: Brain, Mind, Experience and School, ed. J.D. Bransford, A.L. Brown, and R.R. Cocking. Washington, DC: National Academy Press. http://books. nap.edu/books/0309070368/html/index.html (accessed 28 July 2004).

National Research Council. (2003). Bio2010: Transforming Undergraduate Education for Future Research Biologists. Committee on Undergraduate Biology Education to Prepare Research Scientists for the 21st Century. Washington, DC: National Academies Press. http:// www.nap.edu/books/0309085357/html (accessed 28 July 2004).

National Science Board. (2003). The Science and Engineering Workforce. Realizing America's Potential. NSB 0369. Washington, DC: National Science Foundation, Aug. 14, 2003.

National Science Digital Library. (2004). http://www.nsdl.org (accessed 28 July 2004).

Nester, E., Thomashow, L.S., Metz, M., and Gordon, M. (202). 100 Years of Bacillus thuringiensis: A Critical Scientific Assessment. American Academy of Microbiology Critical Issues Colloquia Reports. http://www.asm.org/Academy/index.asp?bid=2129 (accessed 28 July 2004).

The Peer-Led Team Learning (PLTL). (2004). Workshop Project. http://www.sci.ccny.cuny.edu/ chemwksp/index.html (accessed 28 July 2004).

Tanner, K., Liesl, S., Chatman, L.S., and Allen, D.E. (2003). Approaches to cell biology teaching: cooperative learning in the science classroom-beyond students working in groups. Cell Biol. Educ. 2, 1-5. http://www.cellbioed.org/articles/vol2no1/article. cfm?articleID=36 (accessed 28 July 2004).

Undergraduate Technology Apprentice Program (UTAP). (2004). University of Maryland College of Life Sciences/College of Agriculture. http://www.life.umd.edu/utap (accessed 28 July 2004).

University of Buffalo. (2004). National Center for Case Study Teaching in Science. http://ublib.buffalo.edu/libraries/projects/cases/ case.html (accessed 30 July 2004).

University Teaching and Learning Program (UTLP). (2004). University of Maryland, Center for Teaching Excellence. http:// www.cte.umd.edu/UTLPreqs.html (accessed 28 July 2004).

WebCT. (2004). http://www.webct.com/ (accessed 7 February 2005).

Weld, J. (2002). Save your lecture for someone who cares. J. Coll. Sci. Teach. 31(7), 489-490.

Witham, S.A., Krockover, G.H., Ridgeway, K.D., and Zinsmeister, W.J. (2002). Lessons online, educational technology for the undergraduate geology classroom. J. Coll. Sci. Teach. 32(4), 265-269.

Wood, W.B. (2003). Inquiry-based undergraduate teaching in the life sciences at large research universities: a perspective on the Boyer Commission Report. J. Cell Biol. Ed. 2, 112-116. http://www. cellbioed.org/articles/vol2no2/article.cfm?articleID=57 (accessed 28 July 2004). 